Du texte à la scène : langages du théâtre

\title{
Antony and Cleopatra: Penny Plain or Tuppence Coloured
}

James R. Mulryne

\section{(2) OpenEdition}

Journals

\section{Electronic version}

URL: http://journals.openedition.org/shakespeare/466

DOI: 10.4000/shakespeare.466

ISSN: 2271-6424

\section{Publisher}

Société Française Shakespeare

Printed version

Date of publication: 1 November 1983

Number of pages: 93-110

\section{Electronic reference}

James R. Mulryne, «Antony and Cleopatra: Penny Plain or Tuppence Coloured », Actes des congrès de la Société française Shakespeare [Online], 4 | 1983, Online since 01 January 2007, connection on 06 May 2019. URL : http://journals.openedition.org/shakespeare/466 ; DOI : 10.4000/shakespeare.466 
SOCIETE FRANÇAISE SHAKESPEARE

Actes du Congrès 1982

\section{DU TEXTE A LA SCENE : Langages du Théâtre}

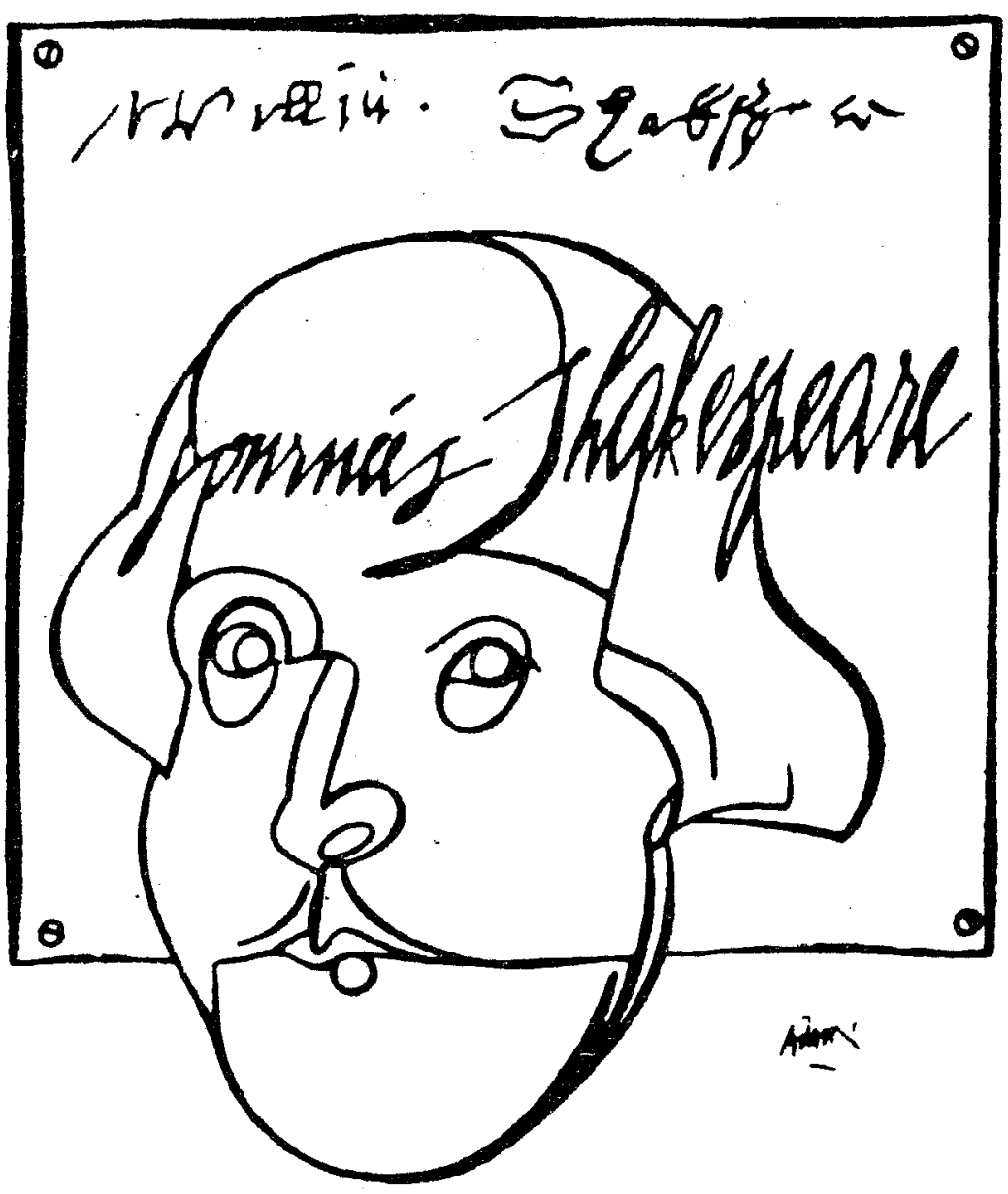

DiRecteur de la publication M.T. Jones - Davies

Publié avec le concours du Centre National de la Recherche Scientifique

JEAN TOUZOT Libraire - Editeur

38 , rue Saint-Sulpice 75278 PARIS CEDEX 061983 
grouping and in the sheer inventiveness and economy with which the visual effects were registered. A gorgeous orangered canopy, supported on long poles, suddenly blossomed like a great exotic flower to convert the otherwise plain setting into Cleopatra's palace. Reviewers commented on the excitement of this and other transformations. Peter Lewis wrote that «The full MGM spectacle is deployed on the cleverly designed stage - a white, stonefaced hollow cube which is converted with a sweep of great canopy into sultry Alexandria». John Barber in the Daily Telegraph described how the stage «suddenly turns itself into Pompey's galley with a great swirl of sail, and for Cleopatra's monument a vast pyramid rises terrifyingly out of the ground, like an exhalation». Amid these sudden splendours, Janet Suzman played Cleopatra as an exotic languishing creature, a fascinating performer always in the public eye and always gratified to be so. The Times reviewer, Charles Lawsen, noticed at the lovers' second encounter «Cleopatra tickling Antony's ear with her big toe to the delight of a full audience of eunuchs, serving maids and debauched soldiers». Suzman, speaking of her role to a Daily Telegraph reporter said that in Cleopatra's Egypt «Everyone lived in public, from the monarch to the poor. I suppose in our day the TV camera has taken over from the court». Thus Cleopatra became one more facet of the spectacle that in this production was Egypt.

Christopher Morley, Nunn's designer, gave the audience a Rome that in its austerity of colour and lack of ornament represented the exact counterpart and complement to his wonderfully sumptuous Egypt. Michael Billington of The Guardian found Rome «a place of brazen trumpets, cold calculation and white knees», the last feature so noticeable no doubt because of the tawny skins of Cleopatra's attendants. The Roman soldiers wore black tunics and carried what seemed to be authentic copies of Roman standards; the inflexibility of the Roman mind was evoked in their movements and drill-like 
groupings. The Roman women ${ }_{b}$ and the men in their offduty moments, wore white, conveying a sense of the gelid emotional life of Rome, off-set but not contradicted by the heartiness of the party on Pompey's barge. Corin Redgrave played Caesar as the epitome of this Roman civilization, severe, shrewd and hermetically selfcontained.

When Trevor Nunn was asked by a newspaperman, John Minthau of the Evening Standard, to comment on the major challenge of presenting Antony and Cleopatra his answer ran:

The crux is finding the balance between the human and the heroic sides of two extraordinary people. They saw themselves as god and goddess, the most powerful and most wealthy people alive. What is finally uncovered is their human stature - the undeniable power of reality in their relationship.

Nunn's emphasis rested, that is to say, on the relationship between two people and the effect of events on it. Certainly, I vividly recall the terrible decline, and with it the savage self-blame, of a once-great general. Some reviewers thought Janet Suzman too bland and too appealing, physically, for Cleopatra. John Barber commented in The Daily Telegraph that she "wears the usual wig and displays a fine figure but does nothing to suggest a woman half-blasted by a too-arduous life, who has had too many children by too many lovers». Yet Suzman played with vitality and wit; Michael Owen of The Evening Standard remarked that «she frisks, she goads, she vamps, she prevaricates, this stunning Cleopatra of Janet Suzman». As performances, therefore, Richard Johnson's Antony and Janet Suzman's Cleopatra carried considerable conviction. If the total effect of the production was less than satisfying, the difficulty lay elsewhere, in the subtle and necessary engagement of the main performances with the rhythms of the piece as a whole. Emrys Jones has written brilliantly, in the New 
Penguin introduction, of «the special dramatic rhythm of Antony and Cleopatra, its teasingly discontinuous movement». The play's human beings, he says «are creatures of internal mood and impulse» and their world is «in perpetual movement»; like the sea, he continues, "whose presence is much felt in the play, reality is «varying»». The visually spectacular production, such as Nunn's, finds it difficult, even impossible, to adjust to these subtle and subtly orchestrated rhythms, devoted as it is to large groupings and large effects. The pictorial splendours of the tuppence coloured tradition are in part no doubt a response to the theatrically unsettling fact that Antony and Cleopatra virtually does without a plot: much happens off-stage and by report, but virtually nothing takes place before our eyes, except in the obsessively active but unprogressive consciousnesses of the main characters. Such a response compensates for and does not convey the special nature of its dramatic text. The visually sumptuous tradition in producing Antony and Cleopatra is a prime example of a dramatic style where we see Shakespeare's «play done by good actors in what seems like the proper way - they look lively and colourful, there is music and everyone is all dressed up» and yet the effect if not deadly is subtly deadening to a crucial aspect of the play's dramatic life.

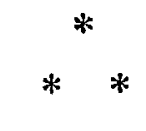

Nunn's Antony and Cleopatra was staged early in the 1970's. In various ways it was an old-fashioned production, both for Nunn and for Stratford. In the later sixties and in the seventies much that was best in theatre in Britain resulted from conceiving theatre not as a place for display but for direct emotional engagement between actor and audience. Intimate, small-scale theatre spaces, like The Traverse in Edinburgh and later The Other Place in Stratford, became the typical locations for the 
most adventurous work; experimental touring companies, such as Joint Stock or Welfare State, laid stress on risk and improvisation in playing. Peter Brook's experimental work, in England, France and abroad, as well as his The Empty Space were symptom and stimulus to this new or newly recovered sense of theatre as risk-taking and spontaneous (or giving the effect of spontaneity). Another symptom, I think it's fair to say, was John Russell Brown's lively and controversial piece of theatre-scholarship, Free Shakespeare (1974). Brown offered to show, in effect, that Shakespeare's theatre shared many of the characteristics that were making contemporary smallscale work in England so exciting : improvisation and audience-engagement in particular and a decline in emphasis on the director-dominated «production». Brown's sense of the spirit of Elizabethan theatre can be summarised in two short quotations. In the first he is talking about the «accidental» nature of an Elizabethan performance :

The only stable and unifying elements were the stage-space and equipment, the words of the text, the skill, art and personalities of individual actors, and the time, place and audience of the occasion. There was no director to conduct the performance, and no critic to call for a revaluation. Each day, as the play was performed, some precarious unity, some occasional coherence, would emerge from that day's special chemistry.

The word «production» was unknown : each performance was itself. It was a theatre for discovery and not for display, for happenings and unexpected conflagrations, and also for lack of fire and inefficient confusion. (p. 48)

Such «spontaneity» as this derives in part from the physical and social conditions of the Elizabethan theatre; it comes also from the necessities of the Elizabethan system of repertory playing. Brown reminds us that the 
company was small; that they may have had as many as thirty plays available for performance at any one time; that they could and did put on no fewer than fourteen plays in a couple of months; that rehearsal time was therefore very short and a run of two or three days the maximum. Acting style in that daylight theatre was no doubt altogether less studied and inward than we know it today. Brown puts the matter this way :

They probably worked less subtly, and must have been more dominating, outgoing, clear, physical. They must have been remarkable and outstanding. They must have acted without pause in order to sustain any illusion of reality or sufficient continuity. They would have been inwardly aware all the time that they could lose their audience, and they could never have relied on the overwhelming established reality of scenery or atmospheric lighting and sound. When an actor stepped on to the stage, the audience would not have been conditioned to take in whatever he offered; rather the actor must have worked to take over the audience (p.51.)

Brown's account of the Elizabethan stage is necessarily speculative, that is to say it is an imaginative reconstruction, for we can never know with certainty what the atmosphere and working style of the Elizabethan theatre were actually like. For present purposes, its important feature is that while on its first appearance the book was greeted with less than full approval, and especially in the professional theatre, it provides nevertheless a kind of theoretical underpinning for certain developments in the performance of Shakespeare's work in the 1970's. Professional theatre never abandoned the director as Brown would have liked, nor did it take the day to day risks he thought characteristic of the Elizabethan stage, yet it did move some way towards his desired goals - as part of a continuing development of theatre 
style, no doubt, and not directly under his influence.

Peter Brook is not one of Brown's heroes in Free Shakespeare; or only a partial hero at best. Yet there are parallels to be drawn between Brown's reconstruction of a vigorous Elizabethan theatre and the set of working conclusions Brook had been reaching over an extended period of theatrical experiment - experiment that included such productions as Marat Sade, US and $A$ Midsummer Night's Dream for the Royal Shakespeare Company, various overseas journeys with a multi-national group of actors, and a continuing series of explorations at the Bouffes du Nord in Paris. The essential finding of Free Shakespeare is that the vitality of Elizabethan theatre derives from the primacy of the theatre moment itself, that is to say it lies in the direct, risk-laden and often unstable engagement of the actor's personality and skills with the alert emotions of a live audience. Brook's discovery of a theatre-language for today would certainly include some such premise. His return to Stratford and to Shakespeare for the 1978 Antony and Cleopatra represented an attempt to renew this major play by releasing it from some of the encumbrances of the pictorial tradition, and so set free its Elizabethan theatrical vitality of word and action. The common consent of audiences and reviewers was that his success was limited, but his choice of playing style and the design decisions he and Sally Jacobs (his designer) made remain of considerable interest.

Brook's production was one of the most eagerlyawaited theatre events of the 1970's. A week before it opened, in October 1978, Brook invited the press to a photo-call. No fewer than fifty photographers from all over the world attended. Speculation about the production was intense, for Brook had ensured that scarcely a word of 


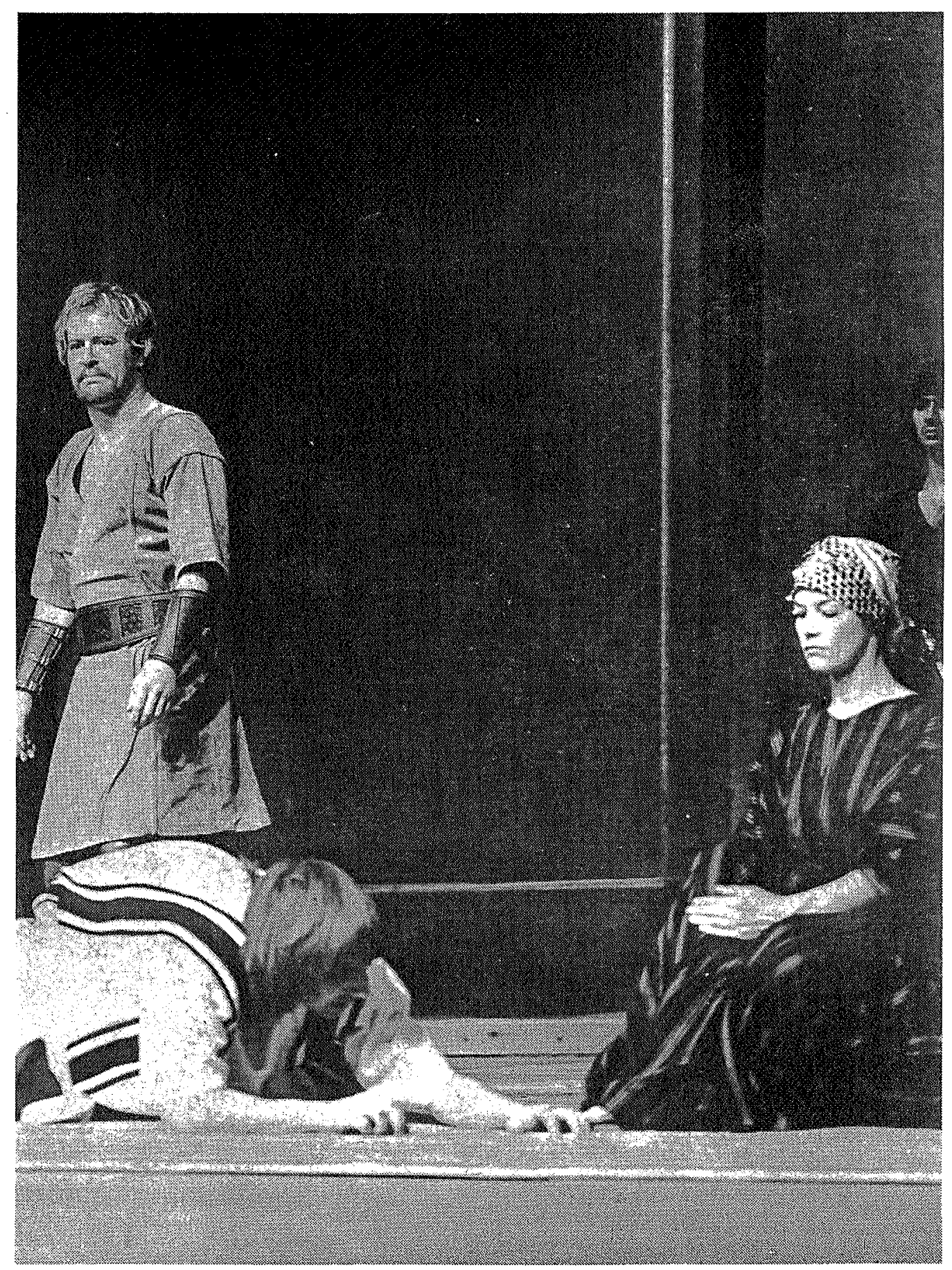

Antony and Cleopatra directed by Peter Brook with Alan Howard as Antony and Glenda Jackson as Cleopatra (Photo Joe Cocks) 
what was intended had leaked during the extra-long rehearsal period of ten weeks. It was expected that Brook would provide some radical solution to the problem of unlocking the play's energies - as he had discovered unsuspected sources of energy twice before in Shakespeare plays at Stratford, the noted interpretations of Titus Andronicus and A Midsummer Night's Dream.

The boldness of Brook's approach to the play was immediately evident. In place of the sumptuous visual pleasures of the traditional Antony and Cleopatra, Brook and Sally Jacobs designed a setting almost wholly lacking in visual appeal. Tall frosted-glass panels were ranged in an arc across the width of the stage, providing a large playing area downstage and a much smaller one, largely hidden from the audience, upstage. This steadfastly unglamorous setting remained unchanged throughout, varied only when in the battle scenes handfuls of red paint, representing gore, were splashed on the screens from behind. Such a setting had the effect of throwing into relief the actors and their gestures. It also ensured that whatever vitality the performance possessed derived immediately from the same source : the physical energy of the players. Or rather the player's energy as a visible counterpart of the wonderfully varied energies of the play's language. The tendency of a visually sumptuous production lies towards slowness and even immobility : visual tableaux that at best summarise or recollect given relationships. The essential movement of Antony and Cleopatra is otherwise, responding to the eddying of impulse and mood. Brook's stage-setting at the least did not hamper the responsiveness of his production to that active varying life.

Further design and casting decisions built upon that initial freedom. Costume, while it alluded to matters Egyptian and Roman, made no attempt at verisimilitude. Cleopatra's own costumes, for example, were either plain self-coloured tunics, worn with a simple headscarf, or for a stronger visual effect, a similar garment in woven 
fabric and striped. An emotionally valid statement was achieved in the robes Cleopatra wore as she committed suicide. These were golden in colour, splendidly vivid and reflective under the lights; but poor and tinselly in texture, as though emphasising the element of «dressing-up» in Cleopatra's performance of dying. A similar awareness of the scene's ironies expressed itself in the detail of Cleopatra's crown. Where Janet Suzman's bejewelled, helmet-like, crown was worn with regal dignity throughout her death-scene, Glenda Jackson's simple coronet had been tilted askew before the lines «Your crown's awry/ I'll mend it and then play». The pathos of the queen's frailty, her inability wholly to transform dying, was not lost in an attention to spectacle. A similar motivation (coupled, it may be with necessary economy) probably explains the sparingness with which attendants were used in Brook's production. Where Nunn's scenes were thronged with extras, many of them exotically made-up and richly dressed, Brook employed few and rather unspectacular non-speaking actors. Janet Suzman remarked on the public lives of Antony and Cleopatra, a reflection of their emotional expansiveness. The effect of Brook's decision was to focus attention rather on the intense personal energy that draws the two together and sweeps them apart. The long absence of Antony makes of Cleopatra an impatient, sometimes aggressive and emotionally frustrated woman. On the thinly-populated stage devised by Peter Brook, the pathos of her time-occupying stratagems becamejeven more pronounced. The need one has for the other, as well as the pride and (for differing reasons) the unwillingness of each to commit himself or herself to the other, was sharply and convincingly etched. Because of design decisions the performance came to centre on and derived its energies from that intense personal attachment and the attractions and antagonisms it spawned. In contrast to Janet Suzman's view of the public nature of her role, Glenda Jackson remarked tellingly on its private aspect : «I found that, although 
it is always being described as an epic play, it's not that at all. They are epic people, but they are making human decisions, suffering human emotions. They are acting out their lives in private rooms and are most intimate in a sense. You get this tremendous sense of millions of people outside, pressing against doors and windows, whose lives depend on these extraordinary beings and Shakespeare does it all in words». (The Observer, 8 October, 1978) Such is Jackson's imaginative reconstruction of what it felt like to act her part in Brook's austere production.

A great deal followed, of course, from Brook's decision to cast Glenda Jackson as Cleopatra. There is evidence that the casting had been discussed many years before, when Miss Jackson had played for Brook in $A$ Midsummer Night's Dream. But it is indicative of this production's emphases that Miss Jackson had to become an actress of mature years before she was ready for the Cleopatra Brook envisaged. Miss Jackson is an actress of great strength of personality, capable of expressing intense erotic energy. She is not conventionally beautiful. In Brook's production her immensely expressive features, strong and mobile, were not made up as Egyptian (Cleopatra, of course, is in history a Macedonian Greek, not an Egyptian, but Shakespeare refers to her «tawny front $)$ ). She therefore had to find the expressiveness of her role in the «infinite variety» Shakespeare specifies, without assistance from the glamour of her surroundings, conventional physical appeal, or exotic costume or makeup. Her success was of a piece with the production's stress throughout on the physical «presence» of the actors, undimmed by spectacle or rich costumes or large groupings.

Other castings re-inforced that of Miss Jackson. Alan Howard was not the first-choice Antony (that was the American actor, Stacey Keach) but his large frame and whole-heartedly physical acting-style confirmed this production's commitment to bodied presence. The monument scene, for example, took its strength from the 
sheer physical weightiness of Antony's dying body, asserting its actuality in opposition to Cleopatra's visionary dreams. (The setting, however, undermined the effect, for there was no balcony and hence no untidy raising of the slack body, merely a drawing of the dying Antony across the stage-floor). The casting of Caesar was more unusual. Jonathan Price is an actor of remarkable nervous energy, very lean and hollow-cheeked, always bringing to his work a hair-trigger sensitivity that is exciting and occasionally even unsettling. His Caesar brought alive the emotions of the scenes with Octavia; made sense of Caesar's participation in the roistering on Pompey's barge (though the self-awareness of his character just held him back from full commitment); and rendered convincing the superstitious belief in Caesar's «daemon» always overshadowing that of Antony. Michael Billington went so far as to describe Price's Caesar as « a man of reckless passion». The effect of this characterisation was to make of the play a three-cornered emotional struggle, and its history much more than usual the outcome of personal impulses and emotions.

Every production secures its effect through its management of the play's rhythms, as well as through the more apparent effects of casting and design. Brook's management of rhythm is impossible to describe in detail, except perhaps by reference to the freedom his avoidance of large grouping and visual effects provided. The very elusive rhythms of the piece - what is known among the literary critics as its «defective construction»-began to fall into place. The play does not move forward in a reassuring narrative arc; instead it eddies to and fro as chance, will and impulse determine. The largely private encounters, and the physical and nervous energy of his actors permitted Brook to adapt his playing style to the tragedy's unprogressive but intensely active life. One scene became the fulcrum of the experience, the typifying instance of the unsteady world of Antony and Cleopatra. This was the scene on Pompey's barge. Where almost every other scene derived from the tensions generated 
between individual actors, this depended on ensemble playing. The cast rehearsed the scene very frequently, but strove to make each performance different and unexpected thus preserving the vitality of the event. As the party grew wilder, the actors joined in a furious dance, hand in hand circling the stage in almost disordered motion. The gathering crescendo of action, scarcely controllable, ultimately collapsed in disarray and exhaustion. Local points about Antony's character and the relationship between the world leaders were conveyed; but much more important, the fragile structure that was power politics, its emotional and circumstantial determinants, seemed physically expressed. A case of action interpreting the implicit sense of the text.

Many were disappointed by Brook's Antony and Cleopatra. Partly this was the result of unfulfilled expectations. The «Tuppence Coloured» tradition was so prominent in the audience's minds that they could not adapt to so very unglamorous a production as Brook's. But partly it was the result of inadequacies in the production itself. The grandeur is part of the «meaning» of Antony and Cleopatra, the spaciousness and the sense of the implicit destiny of a whole world. Brook's production avoided the traps of «deadly» theatre by recovering many of the essential energies of the text. Yet Antony and Cleopatra is more inclusive, even, than Brook was able to represent. We still await a wholly convincing interpretation. When it comes, it will not be Penny Plain nor Tuppence Coloured but both and neither. 